http://ejournal.upi.edu/index.php/jaz/ - e-mail: jurnal.zonasi@gmail.com dan jurnal_zonasi@upi.edu DOI: http://10.17509/jaz.v1i2.12467

\title{
STUDI LAPANGAN VARIABEL IKLIM RUMAH VERNAKULAR PANTAI DAN GUNUNG DALAM MENCIPTAKAN KENYAMANAN TERMALADAPTIF
}

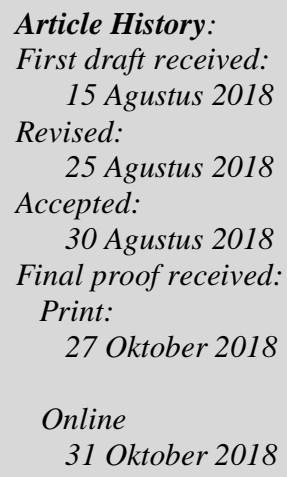

\author{
Hermawan $^{1}$, Eddy Prianto $^{2}$, Erni Setyowati ${ }^{3}$ \\ ${ }^{1}$ Universitas Sains Al Qur'an, Wonosobo, Indonesia \\ ${ }^{2,3}$ Universitas Diponegoro, Semarang, Indonesia \\ 1 Jl. Raya Kalibeber Km.03 Semarang \\ ${ }^{2,3} \mathrm{Jl}$. Prof Sudarto Semarang \\ Email: ${ }^{1}$ hermawanarsit@gmail.com \\ ${ }^{2}$ dr.eddyprianto@gmail.com \\ 3ernisyahdu@gmail.com
}

\begin{abstract}
Microclimate variables are one of the variables that affect adaptive thermal comfort. The microclimate variables are air temperature, solar radiation temperature, air humidity and wind speed. In this study the discussion of microclimate variables is specific to air temperature and air humidity. This is based on other studies which mention that the most influential climate variables are air temperature and humidity. This research is a field study that will compare air temperature and humidity in coastal and mountain areas. Measurements are carried out in 3 seasons, namely the dry season to rain, the rainy season and the rainy season to the dry season. Measurement of air and humidity temperature variables in two rooms in the building and outside space and terrace. The results of the study show that there are significant differences between coastal and mountain dwellings. This difference is related to adaptive thermal comfort through thermal sensation. Thermal sensation results show that the location of the mountain is that most residents feel cool, while at the beach location, the residents are mostly comfortable or neutral.
\end{abstract}

Keywords: climate variable; adaptive, vernacular

\begin{abstract}
Abstrak:Variabel iklim mikro merupakan salah satu variabel yang mempengaruhi kenyamanan termal adaptif. Variabel iklim mikro tersebut yaitu suhu udara, suhu radiasi matahari, kelembaban udara dan kecepatan angin. Pada penelitian ini pembahasan variabel iklim mikro dikhususkan pada suhu udara dan kelembaban udara. Hal ini didasarkan pada penelitian lain yang menyebut bahwa variabel iklim paling berpengaruh adalah suhu udara dan kelembaban. Penelitian ini merupakan penelitian lapangan yang akan membandingkan suhu udara dan kelembaban udara di daerah pantai dan gunung. Pengukuran dilaksanakan pada 3 kali periode musim yaitu musim peralihan kemarau ke hujan, musim hujan dan musim peralihan hujan ke kemarau. Pengukuran varibel suhu udara dan kelembaban udara pada dua ruang dalam bangunan dan ruang luar serta teras. Hasil penelitian menunjukkan adanya perbedaan yang siginifikan antara rumah tinggal pantai dan gunung. Perbedaan tersebut direlasikan dengan kenyamanan termal adaptif melalui sensasi termal. Hasil sensasi termal memperlihatkan bahwa pada lokasi gunung terlihat penghuni sebagian besar merasa sejuk, sedangkan pada lokasi pantai, penghuni sebagian besar merasa nyaman atau netral.
\end{abstract}

Kata Kunci: variabel iklim; adaptif, vernakular

\section{Pendahuluan}

Variabel yang mempengaruhi kenyamanan termal disebut dengan variabel termal. Variabel termal tersebut mempunyai nilai yang berbeda antara lokasi satu dengan lokasi lainnya dan dapat disebut dengan variabel iklim mikro (Maohui Luo, 2016). Perbedaan ketinggian akan berpengaruh pada perbedaan variabel termal yang mengakibatkan perbedaan kenyamanan termal. Variasi suhu di Indonesia dipengaruhi oleh 
ketinggian tempat (altitude) yang dibagi menjadi tiga daerah beda ketinggian yaitu dataran tinggi (pegunungan), dataran rendah dan pesisir (pantai) (Lakitan, 1994). Menurut teori ketinggian Houbolt, korelasi temperatur dan lokasi ketinggian dari permukaan laut (altitude) menunjukkan bahwa suhu maksimum di Indonesia menurun sebesar $0,57^{\circ} \mathrm{C}$ untuk setiap elevasi setinggi $100 \mathrm{~m}$ pada daerah di bawah garis lintang $60^{\circ} \mathrm{C}$ (Samodra \& Santosa, 2006).

Kenyamanan termal merupakan kondisi pikir seseorang yang mengekspresikan kepuasan dirinya terhadap lingkungan termalnya (Hoppe, 2002). Menurut Fanger, kenyamanan termal adalah keseimbangan panas antara badan dan lingkungannya (Fanger, 1982). Kenyamanan termal menurut Fanger disebut dengan kenyamanan termal statik sedangkan kenyamanan termal yang didasarkan pada persepsi penghuni disebut dengan kenyamanan termal adaptif (Luo, Cao, Damiens, Lin, \& Zhu, 2014). Teori kenyamanan termal digunakan untuk memprediksi kenyamanan termal penghuni bangunan. Teori kenyamanan termal Fanger yang dikenal dengan nama Predicted Mean Vote (PMV). Kenyamanan termal adaptif mulai dikembangkan pada tahun 1998 dengan melakukan penelitian pada bangunan berventilasi alami (Humphreys \& Nicol, 1998). Teori kenyamanan termal adaptif menganggap bahwa penghuni bangunan merupakan faktor utama yang menentukan kenyamanan termal sebuah bangunan. Kenyamanan termal adaptif adalah kenyamanan termal menurut pengguna atau penghuni bangunan yang telah beradaptasi terhadap lingkungan. Pada teori kenyamanan termal adaptif berperan iklim lingkungan yang disebut dengan iklim mikro.

Saat ini berkembang teori kenyamanan termal adaptif yang digunakan sebagai dasar penelitian oleh banyak peneliti sampai saat ini. Penelitian kenyamanan termal adaptif berhubungan dengan variabel iklim, persepsi pengguna dan faktor personal termasuk di dalamnya adalah kebiasaan penghuni bangunan (Singh, Mahapatra,, \& Teller, 2015). Penelitian termal adaptif ini merupakan penelitian yang dilaksanakan untuk mengetahui variabel persepsi terhadap kenyamanan termal. Persepsi tersebut diperoleh dengan menggunakan sensasi termal yang telah terstandar oleh ASHRAE (American Standard of Heating, Refrigerating, Air Conditioning Engineer) sebanyak 7 point yaitu dingin, sejuk, agak sejuk, netral, agak hangat, hangat, panas (Nematchoua, Tchinda, Ricciardi, \& Djongyang, 2014). Iklim mikro dipengaruhi oleh 4 faktor yaitu suhu udara, radiasi matahari, kelembaban dan kecepatan angin. Faktor dominan dari iklim mikro yang mempengaruhi kenyamanan termal adalah suhu udara. Suhu udara mempengaruhi kondisi penghuni bangunan. Apabila suhu udara terlalu dingin, penghuni bangunan akan merasa menggigil sehingga tidak bisa beraktivitas dengan baik (Haoran Ning, 2016). Apabila suhu udara terlalu panas, penghuni bangunan akan mengalami stress termal atau efek hyteresis (Nur Dalilah Dahlan, 2016). Fungsi bangunan sebagai wadah beraktivitas menjadi tidak berfungsi apabila kenyamanan termal tidak tercapai. Melihat hal tersebut maka perlu diamati kenyamanan termal rumah tinggal pada daerah tropis dengan suhu udara ekstrim (suhu udara terlalu dingin dan terlalu panas).

Varibel iklim lainnya adalah kelembaban. Kelembaban mempunyai pengaruh yang cukup besar terhadap kenyamanan termal. Salah satu penelitian yang terbaru menemukan adanya pengaruh kelembaban terhadap kenyamanan termal (Modeste Kameni Nematchoua, 2016). Penelitian dilakukan pada bangunan dengan menggunakan bangunan berdinding bata mentah. Material tersebut sama dengan material dinding pada rumah tinggal tradisional di tropis panas sehingga perlu dilakukan perbandingan pengaruh elemen arsitektur pada penciptaan kenyamanan termal di wilayah penelitian.

Prediksi kenyamanan termal pada bangunan atau ruang juga menggunakan teori kenyamanan termal adaptif. Beberapa penelitian tersebut diantaranya adalah penelitian ruang terbuka, bangunan perkantoran, bangunan sekolah, rumah tinggal, Pada penelitian tersebut ditemukan beberapa model matematis kenyamanan termal adaptif pada beberapa bangunan. Model tersebut bisa memprediksi kenyamanan termal pada sebuah bangunan (Alkies Kotopouleas, 2016).

\section{Metode Penelitian}

Rumah sampel adalah rumah batu bata ekspos dan kayu di daerah pantai dan rumah batu ekspos dan kayu di daerah gunung. Daerah pantai diambil di Kabupaten Demak dan daerah gunung diambil di Kabupaten Wonosobo. Penelitian dilakukan pada dua awal musim kemarau dan penghujan. Penelitian menggunakan metode kuantitatif dan kualitatif. Metode kuantitatif digunakan untuk melakukan pengukuran variabel suhu udara dan kelembaban dengan menggunakan alat pengukur termal. Pengukuran variabel dilakukan selama 5 hari setiap jam mulai jam 06.00-22.00 WIB. Setiap pencatatan dilakukan sebanyak 3 x agar pencatatan valid. Ruang yang diukur adalah ruang luar, teras, ruang tamu/keluarga, dapur. Metode kualitatif digunakan untuk pengambilan kuesioner agar memperoleh data sensasi termal dan aktivitas penghuni. Data-data pribadi penghuni diminta dengan wawancara langsung. Pengambilan data kualitatif tersebut dilakukan selama 5 hari dan setiap hari dilakukan pada empat waktu yaitu pagi, siang, sore dan malam. Cara pengambilan data personal 
dilakukan dengan validasi pada tempat yang berbeda. Analisa data kuantitatif menggunakan grafik yang akan memperlihatkan perbedaan suhu udara dan kelembaban ruang luar dan ruang dalam. Grafik tersebut juga akan memperlihatkan perbedaan suhu udara dan kelembaban udara pada saat awal musim hujan, musim hujan dan awal musim kemarau. Analisa data kualitatif akan memperlihatkan kondisi penerimaan sensasi termal penghuni pada empat rumah yang berbeda dan pada awal musim kemarau dan penghujan.

\section{Hasil dan Pembahasan}

Hasil penelitian ditampilkan dalam bentuk grafik yang membandingkan variabel iklim pada empat rumah sampel. Secara keseluruhan musim terlihat suhu udara maupun kelembaban udara untuk dua lokasi pantai dan gunung berbeda mengingat perbedaan adanya perbedaan ketinggian yang cukup jauh antara pantai dan gunung. Lokasi pantai mempunyai ketinggian daerah sekitar $100 \mathrm{mdpl}$, sedangkan gunung mempunyai ketinggian sekitar $1.300 \mathrm{mdpl}$. Lokasi pantai terlihat suhu udara berkisar antara 25-35oC sedangkan pada lokasi gunung terlihat suhu udara berkisar antara 10-26oC. Kelembaban pada lokasi pantai maupun gunung bervariatif dan hampir mirip. Kelembaban udara terlihat berkisar antara 51-91\%.

Rumah Batu Ekspos Gunung

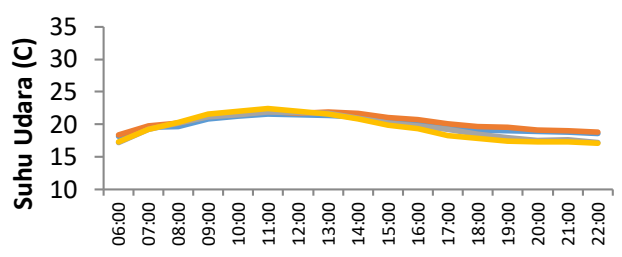

Jam

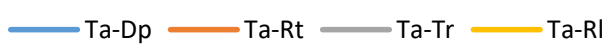

Rumah Kayu Gunung

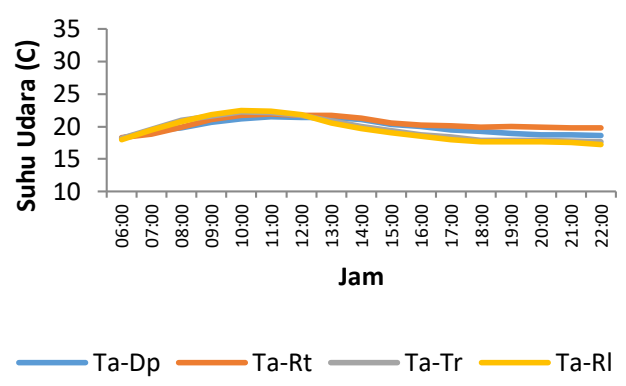

Gb1. Suhu udara di Lokasi Gunung pada musim peralihan kemarau ke hujan

Pada lokasi gunung, perbedaan suhu udara ruang dalam maupun ruang luar untuk rumah batu ekspos dan rumah kayu tidak jauh berbeda. Ruang luar terlihat tidak jauh berbeda dengan dapur (Ta$\mathrm{Dp})$, ruang tamu (Ta-Rt) dan teras (Ta-Tr). Suhu udara yang tertinggi terlihat pada ruang dapur mulai jam 6.00-10.00 WIB, kemudian pada jam 11.00-22.00 WIB terlihat suhu udara tertinggi pada ruang tamu baik untuk rumah batu ekspos maupun rumah kayu. Dapur mempunyai suhu udara tertinggi karena adanya tungku yang dinyalakan pada waktu pagi hari. Tungku digunakan juga untuk memasak. Hal ini relevan dengan suhu udara pada jam pagi merupakan suhu udara rendah. Terlihat pada pagi hari suhu udara mencapai $17^{\circ} \mathrm{C}$.

Rumah Bata Ekspos Pantai

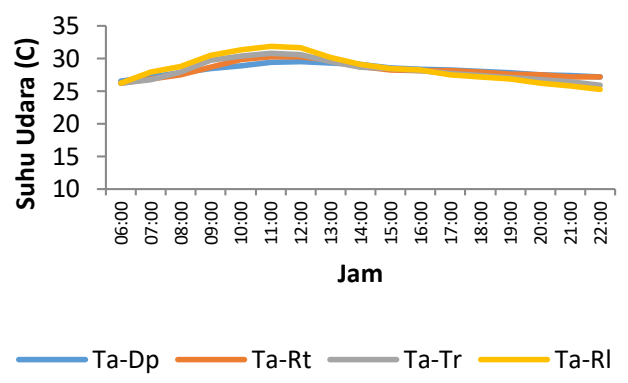

Rumah Kayu Pantai

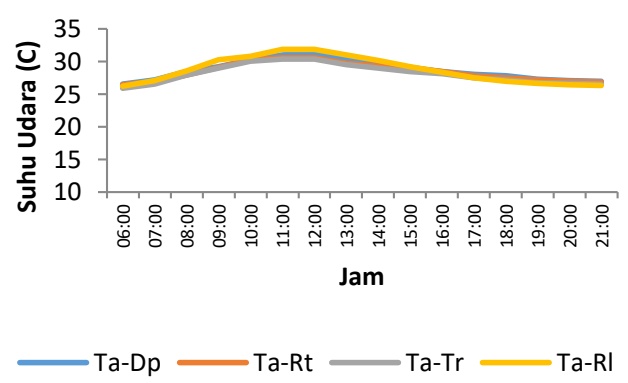

Gb 2. Suhu udara di Lokasi Pantai pada musim peralihan kemarau ke hujan

Pada lokasi pantai, suhu udara terlihat cukup tinggi mengingat lokasi di dataran rendah dengan ketinggian di bawah 400 mdpl. Suhu udara pada pagi hari cukup sejuk berkisar pada angka $25^{\circ} \mathrm{C}$ baik pada rumah bata ekspos maupun pada rumah kayu. Mulai jam 06.00 WIB, suhu udara mulai naik sampai pada jam 12.00 WIB. Kemudian terlihat suhu udara turun mulai jam 13.00-22.00 WIB. Pada pukul 12.00 WIB terlihat puncak tertinggi suhu udara sekitar $33^{\circ} \mathrm{C}$ baik pada rumah bata ekspos maupun rumah kayu. 

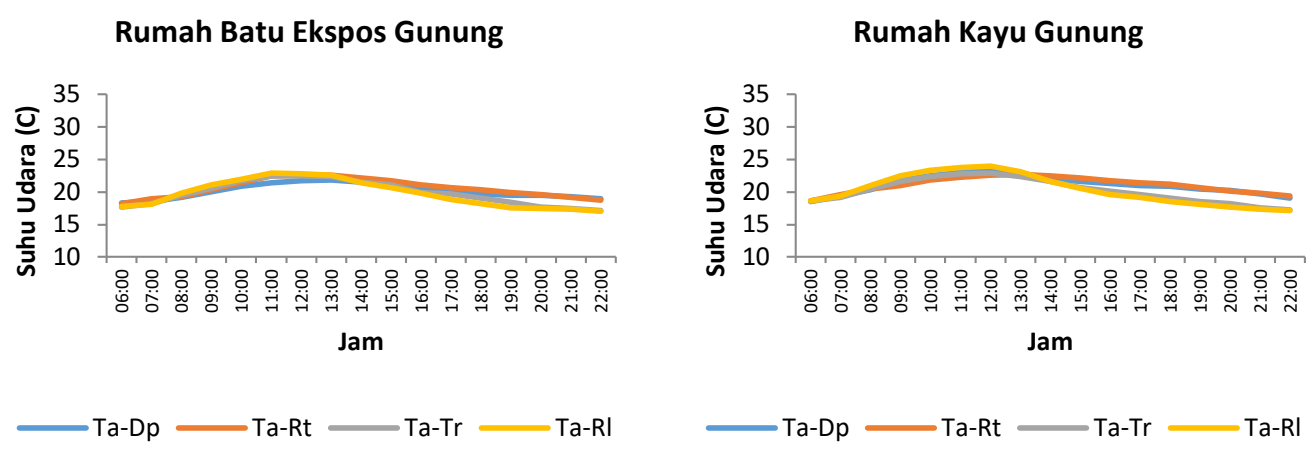

Gb 3. Suhu udara di Lokasi Gunung pada musim hujan

Pada musim hujan terlihat suhu udara di lokasi gunung tidak jauh berbeda dengan kondisi pada saat musim awal hujan. Suhu udara pada lokasi gunung berkisar $15-25^{\circ} \mathrm{C}$, Pada ruang tamu terlihat suhu udara cukup tinggi pada jam 12.00 WIB baik pada rumah batu ekspos maupun rumah kayu. Tren suhu udara pada musim hujan ini sama dengan awal musim hujan yang mulai naik pada jam 06.00 WIB sampai jam 12.00 WIB, kemudian turun pada jam 13.00 WIB sampai jam 22.00 WIB.

Rumah Bata Ekspos Pantai

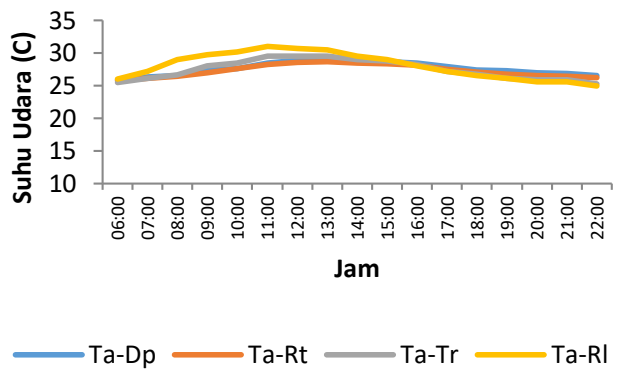

Rumah Kayu Pantai

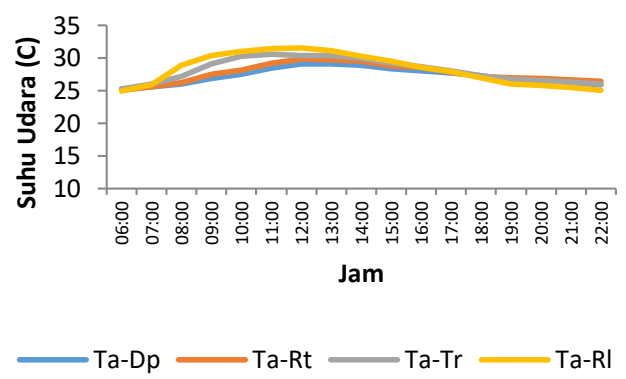

Gb 4. Suhu udara di Lokasi Pantai pada musim hujan

Pada kedua grafik di atas, terlihat suhu udara ruang luar mempunyai jarak dengan suhu udara ruang dalam pada jam 07.00 WIB sampai jam 12.00 WIB. Perbedaan suhu udara ruang luar dan ruang dalam tersebut memperlihatkan bahwa rumah mampu berfungsi mengurangi suhu udara luar dengan cara menurunkan suhu. Penurunan suhu berakibat pada kenyamanan termal penghuni mengingat penurunan suhu bisa mencapai nilai sekitar $26^{\circ} \mathrm{C}$. Ruang dalam yang terlihat paling besar penurunan suhu udaranya adalah ruang dapur.

\section{Rumah Batu Ekspos Gunung}

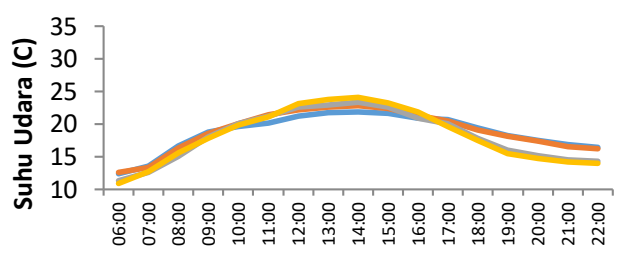

Jam

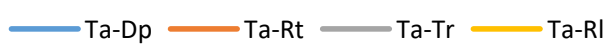

Rumah Kayu Gunung

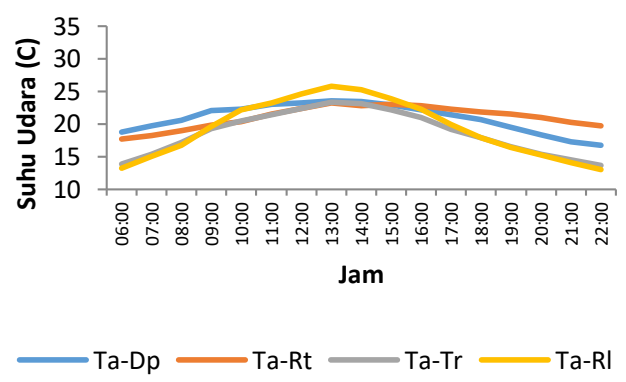

Gb 5. Suhu udara di Lokasi Gunung pada musim peralihan hujan ke kemarau

Pada awal musim kemarau, terlihat suhu udara di lokasi gunung mengalami penurunan yang cukup drastis. Suhu udara terlihat mulai $10^{\circ} \mathrm{C}$ sampai dengan $25^{\circ} \mathrm{C}$. Mulai jam $06.00 \mathrm{WIB}$ suhu udara 
semakin naik sampai jam 13.00 WIB, kemudian turun sampai jam 22.00 WIB. Pada musim awal kemarau ini, suhu udara di rumah batu ekspos gunung terlihat tidak jauh berbeda dengan musim berikutnya, namun ada sedikit selisih yang cukup lebar antara suhu udara ruang luar dengan ruang tamu. Pada rumah kayu gunung, terlihat perbedaan suhu udara yang cukup lebar antar ruang.

Rumah Bata Ekspos Pantai

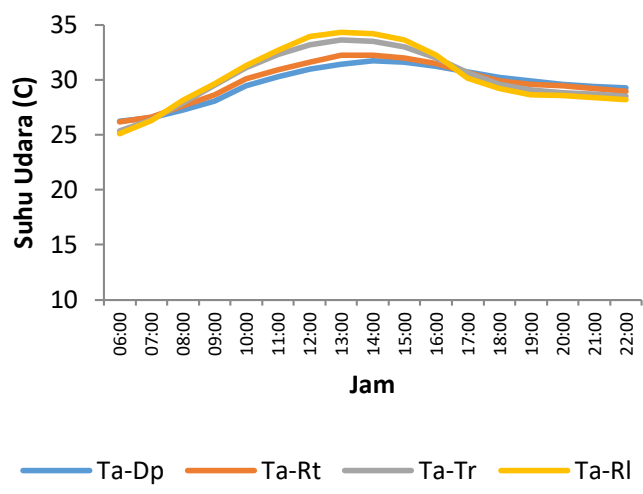

Rumah Kayu Pantai

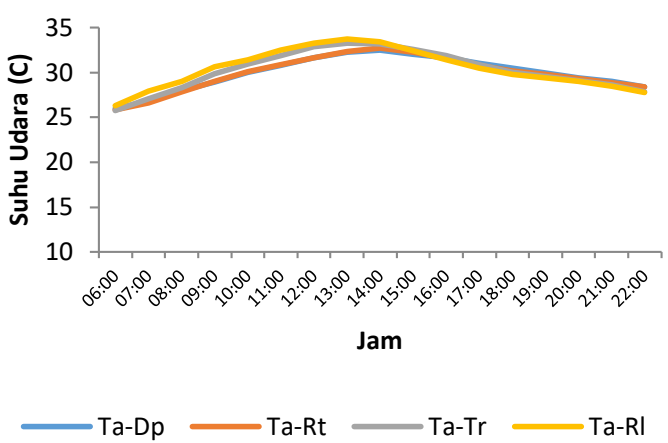

Gb 6. Suhu udara di Lokasi Pantai pada musim peralihan hujan ke kemarau

Pada rumah di lokasi pantai baik rumah bata ekspos maupun kayu untuk musim awal kemarau tidak begitu ada gap antara ruang luar dan ruang dalam. Demikian juga halnya pada musim hujan dan awal musim hujan, tren perilaku suhu udara tidak begitu besar terlihat gapnya. Suhu udara mulai jam 06.00 WIB naik sampai jam 13.00 WIB dan turun kembali sampai jam 22.00 WIB.

Rumah Batu Ekspos Gunung

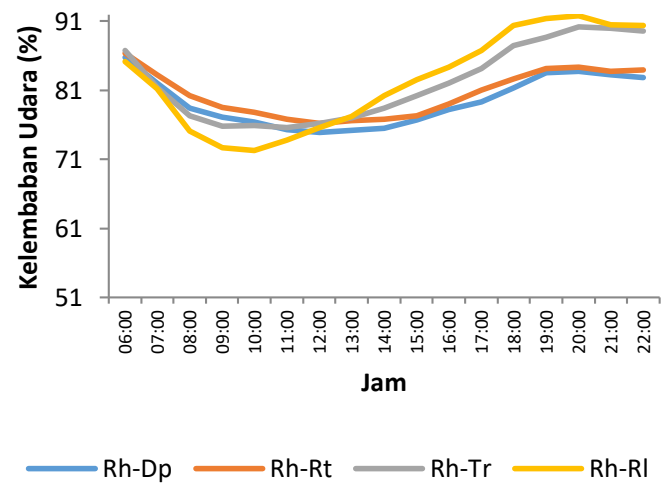

Rumah Kayu Gunung

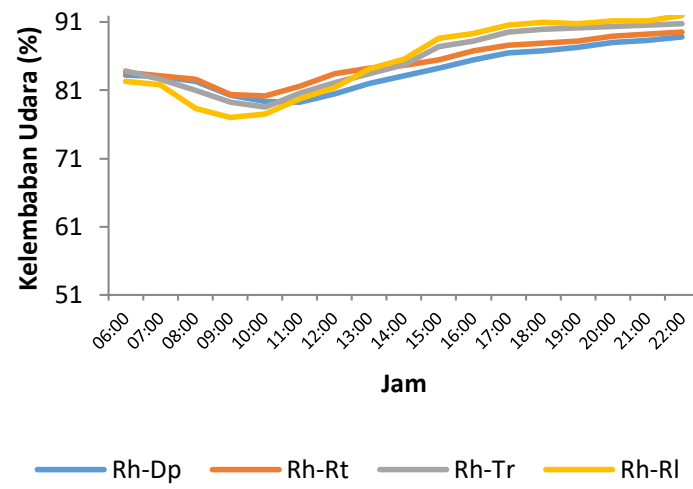

Gb 7. kelembaban udara di Lokasi Gunung pada musim peralihan kemarau ke hujan

Tren kelembaban udara pada lokasi gunung bervariatif. Pada jam 06.00 WIB terlihat kelembaban udara mulai turun sampai jam 09.00 WIB, kemudian naik sampai jam 19.00 WIB. Setelah itu, kelembaban agak datar cenderung turun sampai pukul 22.00 WIB. Pada awal pengukuran yaitu pukul 06.00 terlihat kelembaban udara sekitar 81-86 \% pada rumah batu ekspos dan kayu. Kelembaban tertinggi sekitar 91\%. Selisih kelembaban pada ruang luar dan dalam juga bervariatif. Kecenderungan pada rumah batu ekspos gunung mempunyai selisih kelembaban udara yang cukup lebar antara ruang luar dan ruang dalam. 
Rumah Bata Ekspos Pantai

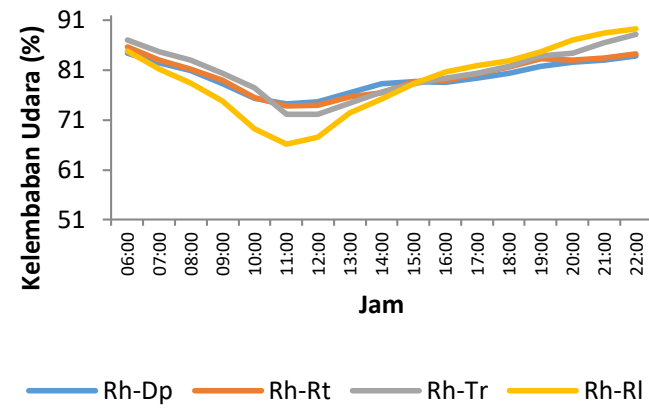

Rumah Kayu Pantai

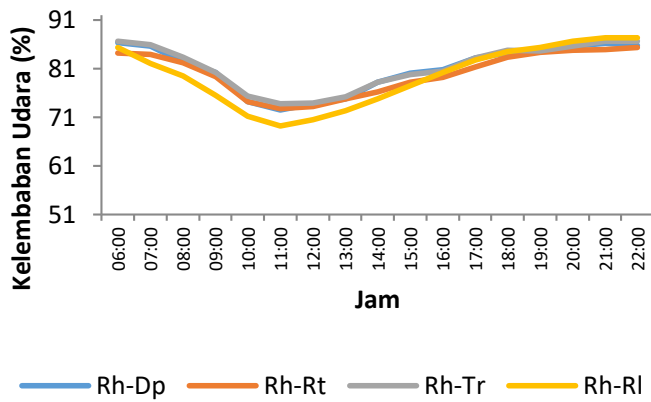

Gb 8. kelembaban udara di Lokasi pantai pada musim peralihan kemarau ke hujan

Kelembaban udara pada lokasi pantai berbeda dengan lokasi gunung. Pada pantai kecenderungan kelembaban udara lebih rendah karena daerah pantai yang cenderung kering. Pada pantai terlihat kelembaban udara sampai pada angka sekitar $62 \%$. Tren kelembaban udara menurun mulai jam 06.00 WIB sampai jam 11.00 WIB. Kelembaban udara naik lagi pada sampai pada jam 22.00 WIB. Selisih antara ruang dalam dan ruang luar terlihat berbeda agak jauh untuk rumah bata ekspos pantai. Hal ini didasarkan pada jenis material bata yang lebih lama menyimpan air.
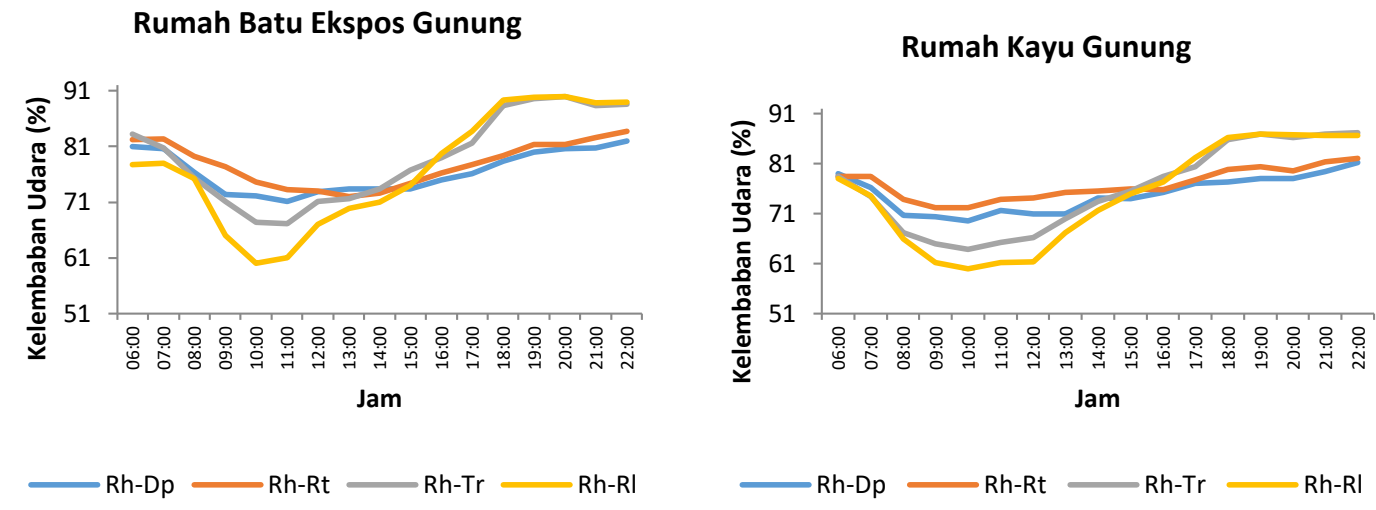

Gb 9. kelembaban udara di Lokasi Gunung pada musim hujan

Pada musim hujan, kelembaban udara di lokasi gunung bervariatif juga seperti pada musim awal hujan. Selisih ruang luar dan ruang dalam pada rumah batu ekspos dan kayu mirip. Fluktuasi kelembaban udara terlihat pada kedua rumah di lokasi gunung. Kelembaban terendah pada angka $70 \%$ baik pada ruang dalam baik rumah batu ekspos maupun rumah kayu. Kelembaban ruang dalam terlihat datar. Pada saat jam 06.00 WIB sampai dengan jam 14.00 WIB, kelembaban ruang dalam lebih tinggi dibanding kelembaban udara pada ruang luar. Pada saat jam 14.00 WIB sampai dengan jam 22.00 WIB, kelembaban udara ruang dalam lebih rendah dibanding ruang luar. Hal ini berlaku untuk kedua rumah di lokasi gunung.
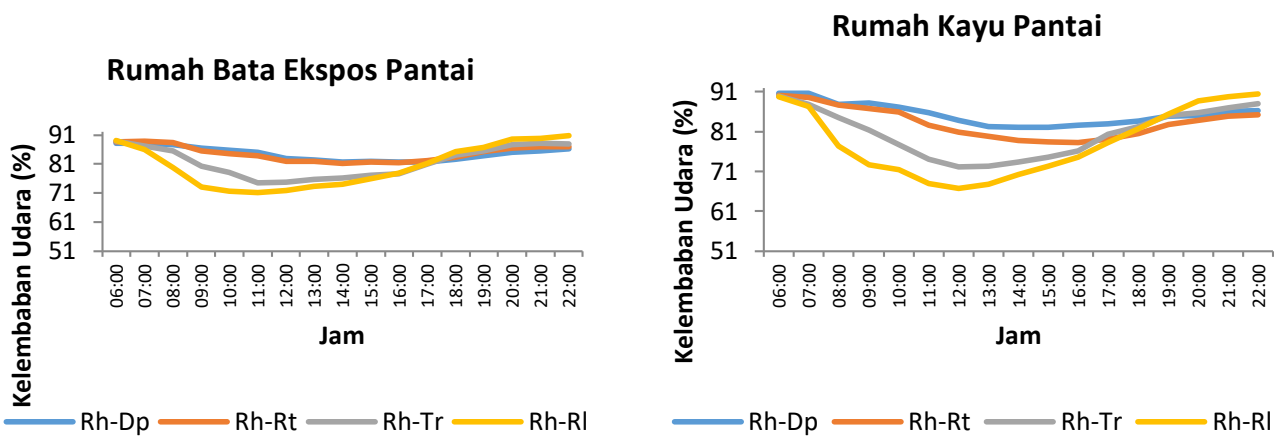

Gb 10. kelembaban udara di Lokasi Pantai pada musim hujan 
Tren kelembaban udara pada lokasi pantai berbeda dengan lokasi gunung terlihat titik perubahan ada dua yaitu pada jam 12.00 WIB dan jam 21.00 WIB. Pada jam 06.00 WIB sampai dengan jam $12.00 \mathrm{WIB}$, terlihat kelembaban udara turun dari 91\% sampai pada angka sekitar $62 \%$. Setelah itu, pada jam 12.00 WIB sampai jam 21.00 WIB naik menjadi 90\%. Pada jam 21.00-22.00 WIB, kelembaban udara datar tidak begitu terlihat naik atau turunnya. Selisih ruang dalam dan ruang luar pada kedua rumah juga lebar pada jam 06.00 WIB sampai dengan jam 13.00 WIB. Sedangkan jam selanjutnya sampai jam 22.00 WIB selisih kelembaban udara antara ruang luar dengan ruang dalam tidak begitu besar.
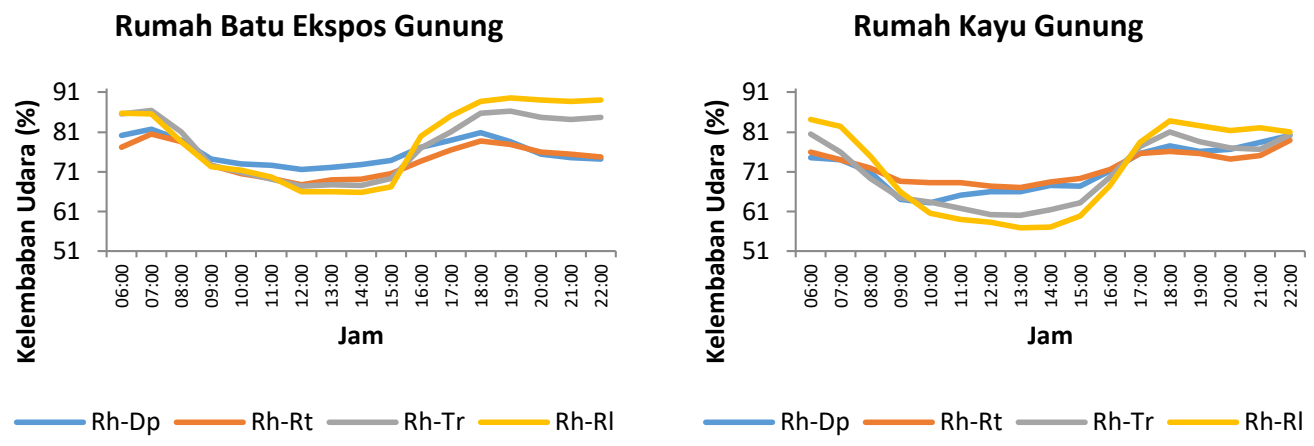

Gb 11. kelembaban udara di Lokasi Gunung pada musim peralihan hujan ke kemarau

Pada awal musim kemarau terlihat kelembaban udara di lokasi gunung tidak beraturan dan terlihat sangat bervariatif. Hal ini terkait dengan suhu udara yang sangat rendah. Perbedaan antara kelembaban pada ruang luar dan ruang dalam menjadi variatif juga. Pada jam 06.00 WIB sampai jam 07.00 WIB, kelembaban agak datar tidak berubah, kemudian pada jam 07.00 WIB sampai jam 15.00 WIB, kelembaban udara terlihat naik cukup besar sampai jam 18.00 WIB. Setelah itu, kelembaban udara tidak begitu mengalami perubahan sampai jam 22.00 WIB.

Rumah Bata Ekspos Pantai

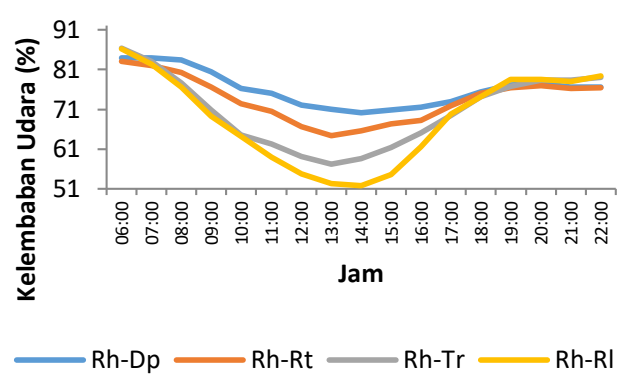

Rumah Kayu Pantai

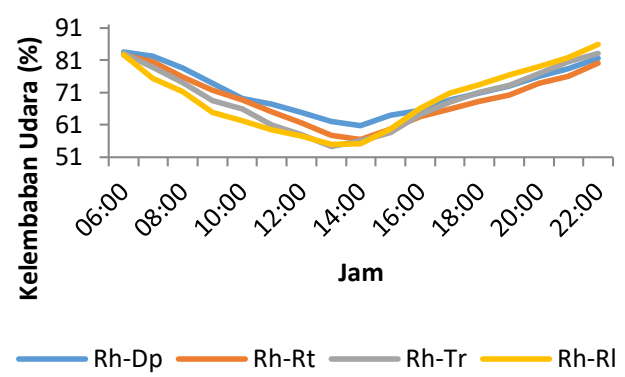

Gb 12. kelembaban udara di Lokasi Pantai pada musim peralihan hujan ke kemarau

Pada lokasi pantai di musim awal kemarau, kelembaban udara pada rumah bata ekspos dan kayu berbeda agak jauh. Selisih kelembaban udara pada rumah bata ekspos mempunyai perbedaan yang cukup lebar dibanding dengan kelembaban udara pada rumah kayu. Pada rumah bata ekspos, jam 06.00 WIB sampai pada jam 13.00 WIB, kelembaban udara cenderung menurun, kamudian naik lagi pada jam 19.00 WIB. Setelah jam 19.00 WIB, kelembaban udara cenderung datar. Pada rumah kayu mempunyai kelembaban udara yang berbeda yaitu mengalami perubahan pada satu waktu saja. Pada jam 06.00 WIB sampai jam 14.00 WIB, kelembaban udara menurun, kemudian setelah itu, kelembaban udara naik lagi sampai jam 22.00 WIB.

Pada penelitian kenyamanan termal adaptif, variabel termal dikaitkan dengan sensasi termal (Hermawan et al, 2015). Hasil sensasi termal pada musim pancaroba awal hujan dapat dilihat pada tabel 1 . 
Tabel 1. Sensasi Termal Penghuni pada musim pancaroba untuk rumah batu gunung selama 5 hari

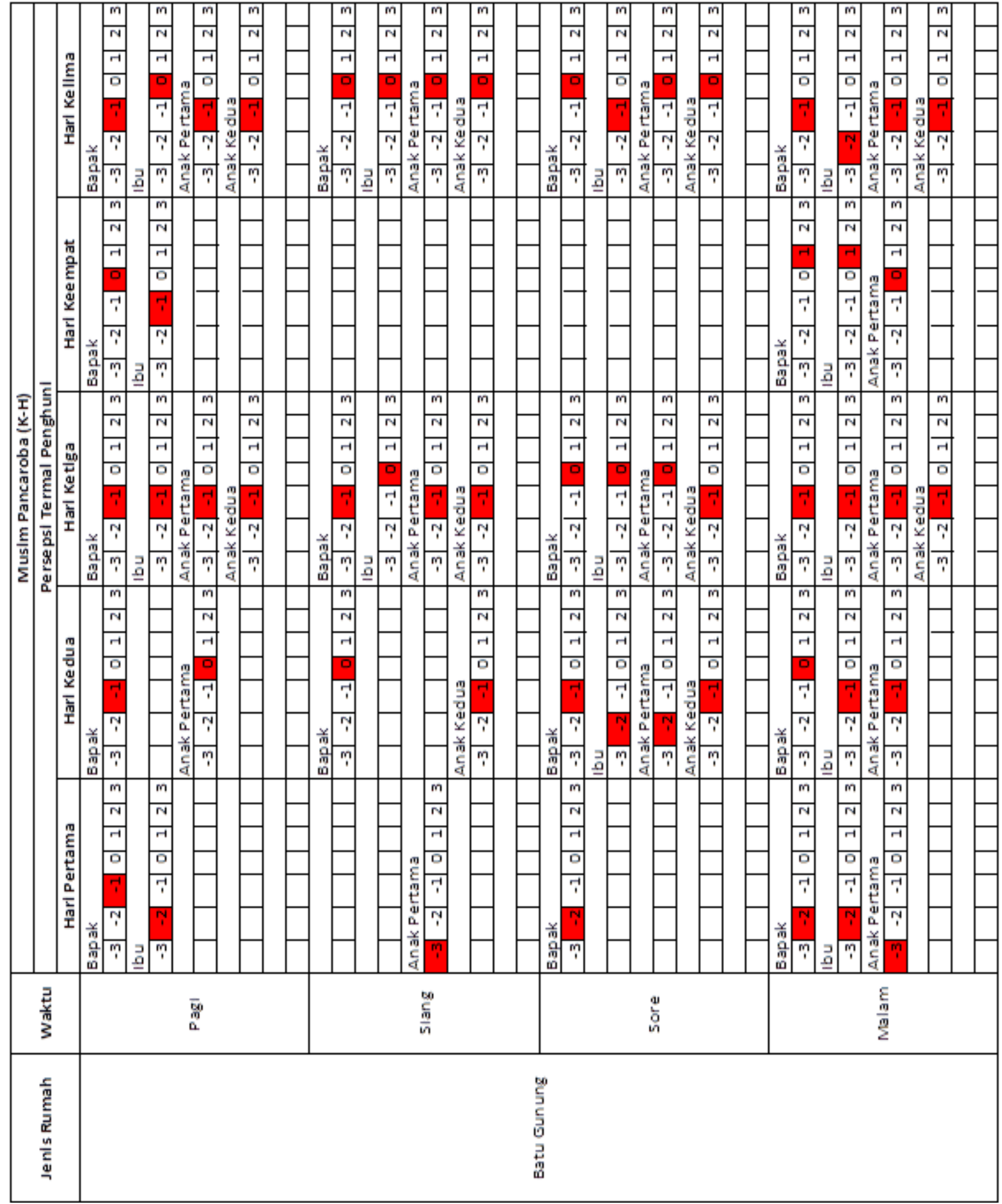


Variabel termal mempunyai kaitan dengan kenyamanan termal adaptif yang diwujudkan dalam persepsi termal yang terdiri dari 7 skala pengukuran yaitu -3 (sangat dingin), -2 (dingin), -1 (sejuk), 0 (nyaman), +1 (hangat), +2 (panas), +3 (sangat panas). Cara pengumpulan variabel kenyamanan termal dengan cara melakukan wawancara dengan penghuni secara langsung. Perbandingan kenyamanan termal adaptif pada lokasi gunung dan pantai yang dilihat dengan sensasi termal menggunakan data AMV (Hermawan et al, 2017). Rekap sesnsasi termal yang didapat pada tiga musim dapat dilihat pada tabel 2.

Tabel 2. Rekapitulasi Persentase Nilai Sensasi Termal

\begin{tabular}{|c|c|c|c|c|c|c|c|c|c|}
\hline \multirow{2}{*}{ No } & \multirow{2}{*}{$\begin{array}{l}\text { Periode } \\
\text { Musim }\end{array}$} & \multirow{2}{*}{ Jenis Rumah } & \multicolumn{7}{|c|}{ Persentase Nilai Sensasi Termal } \\
\hline & & & -3 & -2 & -1 & 0 & 1 & 2 & 3 \\
\hline \multirow{4}{*}{1} & \multirow{4}{*}{ Awal Hujan } & Rumah Batu Gunung & $0,2 \%$ & $0,9 \%$ & $3,3 \%$ & $2,1 \%$ & $0,2 \%$ & $0,0 \%$ & $0,0 \%$ \\
\hline & & Rumah Kayu Gunung & $0,6 \%$ & $3,3 \%$ & $1,8 \%$ & $0,6 \%$ & $0,6 \%$ & $0,2 \%$ & $0,0 \%$ \\
\hline & & Rumah Bata Pantai & $0,0 \%$ & $0,2 \%$ & $2,5 \%$ & $1,2 \%$ & $0,9 \%$ & $0,4 \%$ & $0,0 \%$ \\
\hline & & Rumah Kayu Pantai & $0,0 \%$ & $0,9 \%$ & $0,4 \%$ & $0,2 \%$ & $2,1 \%$ & $0,7 \%$ & $0,1 \%$ \\
\hline \multirow{4}{*}{2} & \multirow{4}{*}{ Musim Hujan } & Rumah Batu Gunung & $0,9 \%$ & $3,7 \%$ & $2,1 \%$ & $0,7 \%$ & $3,1 \%$ & $0,7 \%$ & $0,0 \%$ \\
\hline & & Rumah Kayu Gunung & $0,0 \%$ & $2,0 \%$ & $3,0 \%$ & $3,0 \%$ & $1,2 \%$ & $0,2 \%$ & $0,0 \%$ \\
\hline & & Rumah Bata Pantai & $0,0 \%$ & $1,1 \%$ & $1,6 \%$ & $3,0 \%$ & $1,5 \%$ & $0,2 \%$ & $0,0 \%$ \\
\hline & & Rumah Kayu Pantai & $0,0 \%$ & $0,6 \%$ & $2,0 \%$ & $3,7 \%$ & $2,3 \%$ & $0,6 \%$ & $0,1 \%$ \\
\hline \multirow{5}{*}{3} & \multirow{5}{*}{$\begin{array}{c}\text { Awal } \\
\text { Kemarau }\end{array}$} & Rumah Batu Gunung & $0,7 \%$ & $2,1 \%$ & $5,7 \%$ & $0,0 \%$ & $2,5 \%$ & $0,0 \%$ & $0,0 \%$ \\
\hline & & Rumah Kayu Gunung & $0,0 \%$ & $2,8 \%$ & $4,7 \%$ & $0,9 \%$ & $2,8 \%$ & $0,0 \%$ & $0,0 \%$ \\
\hline & & Rumah Bata Pantai & $0,0 \%$ & $0,0 \%$ & $0,0 \%$ & $4,3 \%$ & $1,7 \%$ & $1,1 \%$ & $0,0 \%$ \\
\hline & & Rumah Kayu Pantai & $0,1 \%$ & $2,8 \%$ & $1,7 \%$ & $1,2 \%$ & $1,6 \%$ & $2,1 \%$ & $0,0 \%$ \\
\hline & & & $2,6 \%$ & $20,5 \%$ & $28,7 \%$ & $21,0 \%$ & $20,6 \%$ & $6,4 \%$ & $0,2 \%$ \\
\hline
\end{tabular}

Presentase terbesar pada lokasi gunung adalah sensasi termal -1 sebesar 5,7 \% yang didapat pada rumah batu gunung. Sedangkan pada lokasi pantai sensasi termal terbesar adalah 0 sebesar 4,3\%. Hal ini menandakan bahwa kebanyakan penghuni mempunyai sensasi termal sejuk di gunung dan merasakan nyaman di pantai. Dilihat secara keseluruhan baik di lokasi pantai maupun gunung terlihat penghuni merasakan sejuk sebesar 28,7\%. Perasaan kedua adalah perasaan nyaman atau netral. Pada penelitian kenyamanan termal sebelumnya didapat bahwa perasaan sejuk pada rumah tinggal batu eskpos karena adanya suhu udara dingin yang terjadi pada pegunungan. Model rumah tinggal batu ekpos lebih dingin dibanding rumah tinggal kayu (Hermawan dan Prianto, 2017).

\section{Kesimpulan}

Varaibel termal antara rumah vernakular di pantai dan gunung menunjukkan perbedaan yang cukup besar mengingat ketinggian kedua lokasi tersebut berbeda. Hasil penelitian menyebutkan bahwa rumah kayu gunung mampu membuat suhu udara dalam ruangan menjadi lebih hangat dibanding suhu udara luar ruangan. Pada diagram terlihat juga rumah bata ekspos pantai dan kayu pantai hampir setara dalam mendinginkan ruangan. Pada jam tertentu, terkadang bata ekspos pantai lebih mampu mendinginkan ruangan, namun pada jam lainnya terlihat kayu pantai lebih mampu mendinginkan ruangan dibanding bata ekspos. Ketinggian lokasi akan mempengaruhi variabel termal sehingga aktivitas penghuni pun akan menyesuaikan dengan lokasi. Kenyamanan termal adaptif yang dilihat dari sensasi termal terlihat berbeda antara lokasi gunung dan pantai. Variabel termal mempunyai pengaruh pada kenyamanan termal adaptif di daerah gunung dan pantai tropis. Hasil penelitian memperlihatkan pengaruh suhu udara dan kelembaban udara pada sensasi termal di daerah tropis pantai dan gunung. 


\section{Referensi}

Alkies Kotopouleas, M. N. (2016). Thermal Comfort conditions in airport terminals: Indoor or transition spaces? Building and Environment, 184-199.

Fanger, P. O. (1982). Thermal Comfort : Analysis and Applications in Environmental Engineering. Florida: Robert E.Krieger Publishing Company.

Haoran Ning, Z. W. (2016). Adaptive termal comfort in university dormitories in severe cold area of China. Building and Environment 99 , 161-169.

Hermawan and Prianto, E., 2017, Thermal evaluation for exposed stone house with quantitative and qualitative approach in mountainous area, Wonosobo, Indonesia, IOP Conf. Series: Earth and Environmental Science 99 (2017) 012017, pp.1-10. do i :10.1088/1755-1315/99/1/012017

Hermawan, Prianto, E., and Setyowati, E., 2015, The difference of thermal performance between houses with wooden walls and exposed brick walls in tropical coasts, Procedia Environmental Sciences 23 (2015) $168-174$

Hermawan, Prianto, E., Setyowati, E., and Sunaryo, 2017, The comparison of vernacular residences' thermal comfort in coastal with that in mountainous regions of tropical areas, AIP Conference Proceedings 1903, 080001 (2017), pp. 080001-1 - 080001-8. https://doi.org/10.1063/1.5011589

Hoppe, P. (2002). Different Aspects of Assessing of Indoor \& Outdoor Thermal Comfort. Energy and Buildings Journal .

Humphreys, M. A., \& Nicol, J. F. (1998). Understanding the Adaptive Approach to Thermal Comfort. ASHRAE Transactions, ProQuest Science Journals.

Lakitan, B. (1994). Dasar-dasar Klimatologi. Jakarta: Raja Grafindo Persada.

Luo, M., Cao, B., Damiens, J., Lin, B., \& Zhu, Y. (2014). Evaluating thermal comfort in mixed-mode buildings: A field study in a subtropical climate. Building and Environment, 1-9.

Maohui Luo, W. J. (2016). Indoor climate and thermal physiological adaptation: Evidences from migrants ith different cold indoor eposures. Building and Environment 98 , 30-38.

Nematchoua, M. K., Tchinda, R., Ricciardi, P., \& Djongyang, N. (2014). A field study on thermal comfort in naturally-ventilated buildings located in the equatorial climatic region of Cameroon. Renewable and Sustainable Energy Reviews , 381-393.

Nur Dalilah Dahlan, Y. Y. (2016). Thermal sensations and comfort investigations in transient conditions in tropical office. Applied Ergonomics , 169-176.

Samodra, F. T., \& Santosa, M. (2006). Pola Penghunian dalam Transformasi Altitude dan Kontribusinya dalam Sistem Ventilasi Rumah Tinggal Pedesaan, Seminar Nasional : Transformasi Teknologi untuk Peningkatan Kualitas Hidup Manusia. Yogyakarta: Universitas Teknologi Yogyakarta.

Singh, M. K., M. S., \& Teller, J. (2015). Development of thermal comfort models for various climatic zones of North-East India. Sustainable Cities and Society, 133-145. 